\title{
Acute effects of graduated compression stockings on oxidative stress and muscle damage markers in garbage collectors: a randomized, crossover-controlled trial
}

\section{Efeito agudo do uso de meias de compressão graduada sobre marcadores de estresse oxidative e de dano muscular em coletores de lixo: um ensaio clínico randomizado cruzado}

\author{
Aline M. Araujo ${ }^{1}$ \\ (D) https://orcid.org/0000-0002-5457-7863 \\ Rodrigo K. Cardoso ${ }^{1}$ \\ (D) https://orcid.org/0000-0002-0914-1251 \\ Rafael B. Orcy ${ }^{2}$ \\ (i) https://orcid.org/0000-0002-5896-0202 \\ Francieli M. Stefanello ${ }^{3}$ \\ (D) https://orcid.org/0000-0001-5945-3723 \\ Matheus P. de Freitas ${ }^{1}$ \\ (D) https://orcid.org/0000-0001-7993-3978 \\ Pathise S. Oliveira ${ }^{3}$ \\ (1D) https://orcid.org/0000-0002-8321-7402 \\ Mayara S. Soares ${ }^{3}$ \\ (D) https://orcid.org/0000-0002-2181-3591 \\ Roselia M. Spanevello ${ }^{3}$ \\ (D) https://orcid.org/0000-0002-5117-2000 \\ Airton J. Rombaldi ${ }^{1}$ \\ (D) https://orcid.org/0000-0002-6707-814X
}

Abstract - Intense physical activity can increase oxidative stress and muscle damage in, causing fatigue and injury. Graduated compression stockings (GCS) can decrease these deleterious effects. The aim was to determine the acute effects of GCS on muscle damage and oxidative stress (OS) in garbage collectors. Thirteen garbage collectors, $25.4 \pm 5.2$ years, participated using GCS or placebo stockings. Blood samples were collected at pre and post a working day and after 16 hours of rest. Markers of OS and muscle damage were evaluated. Two-way ANOVA (two conditions and two moments) was used for the analysis of the outcomes No significant differences were found for creatine kinase, catalase and glutathione peroxidase between the time and groups. There was a significant difference for the total thiol content and superoxide dismutase only in the control group (pre and post, $p=0.004$ ). The use of GCS exerted acute protection against the increase of markers of OS, but did not contribute to attenuate muscle damage.

Key words: Catalase; Creatine kinase; Glutathione peroxidase.

Resumo - Atividade física intensa pode aumentar o estresse oxidativo e danos musculares, causando fadiga e lesões. As meias de compressão graduada $(M C G)$ podem diminuir esses efeitos deletérios. $O$ objetivo foi determinar os efeitos agudos da MCG no dano muscular e estresse oxidativo (EO) em coletores de lixo. Treze coletores de lixo, 25,4 \pm 5,2 anos, participaram usando MCG ou placebo. As amostras de sangue foram coletadas antes e após um dia útil e após 16 horas de descanso. Marcadores de EO e dano muscular foram avaliados. ANOVA de duas vias (duas condiçöes e dois momentos) foi usada para á análise dos resultados. Não foram encontradas diferenças significativas para creatina quinase, catalase e glutationa peroxidase entre o tempo e os grupos. Houve uma diferença significativa para o conteúdo total tiólico e superóxido dismutase apenas no grupo controle (pré e pós, $p=0,004$ ). $O$ uso de $M C G$ exerceu proteção aguda contra o aumento de marcadores de EO, mas não contribuiu para atenuar danos musculares.

Palavras-chave: Catalase; Creatina quinase; Glutationa peroxidase.
1 Federal University of Pelotas. Post-graduation Program in Physical Education. Pelotas, RS. Brazil

2 Federal University of Pelotas. Biology Institute. Pelotas, RS. Brazil

3 Federal University of Pelotas. Post-graduation Program in Biochemistry and Bioprospection. Pelotas, RS. Brazil.

Received: December 10, 2019 Accepted: April 10, 2020

How to cite this article Araujo AM, Cardoso RK, Orcy RB, Stefanello R, Freitas MP, Oliveira PS, Soares M, Spavenello RM, Rombaldi AJ. Acute effects of graduated compression stockings on oxidative stress and muscle damage markers in garbage collectors: a randomized, crossover-controlled trial. Rev Bras Cineantropom Desempenho Hum 2020, 22:e70607. D0l: http://dx.doi. org/10.1590/1980-0037.2020v22e70607

Copyright: This work is licensed under a Creative Commons Attribution 4.0 International License. 


\section{INTRODUCTION}

The workers collecting manual garbage suffer from great physical exhaustion during the task, as physical activity reaches levels greater than 3,800 minutes per week, from this time more than 1,500 minutes in vigorous physical activities. Due to the excess of intensive work, musculoskeletal damages are frequent in these workers ${ }^{1}$. It has been well reported in the literature that intense and prolonged physical exercise may cause increased muscle damage and oxidative stress ${ }^{2}$.

Graduated compression stockings (GCS) are among the several resources that science considers to mitigate the damages in the locomotor system $^{3}$ in order to reduce impact from excessive physical activities. GCS aim to soften the impact that excessive physical exercise cause in the skeletal muscle fibers, favoring exercise recovery, lowering lactate levels and reducing trauma and post-exercise muscle pain ${ }^{4}$. Sports studies have shown that GCS reduce muscle fatigue levels in runners ${ }^{5}$ and decrease muscle damage markers such as creatine kinase (CK) and lactate dehydrogenase ${ }^{4}$.

Thus, using GCS may bring benefits to garbage collectors, since the physical activity demanded in the routine of these workers can be compared to the one of athletes ${ }^{6}$. To the best our knowledge, no studies have been performed to verify the efficacy of GCS in muscle damage and oxidative stress markers in garbage collectors.

Therefore, the present study aims to investigate the acute effects of GCS on muscle damage and oxidative stress markers in a sample made up of garbage collectors.

\section{METHODS}

\section{Study population}

A double-blind crossover design study was conducted. The subjects were randomly selected from a total of 76 city garbage collectors. The inclusion criteria were: subjects who were active for at least two months in the collection routine and who did not present physical or psychological limitations. Sample size calculation considering beta of $80 \%$ and alpha of $95 \%$ was performed according to previous studies ${ }^{7,8}$, totaling 12 subjects.

\section{Ethical approval}

The study was submitted and approved by the Research Ethics Committee of the Federal University of Pelotas under number 60777916.2.0000.5313. Ethical principles were ensured and all participants signed an informed consent form.

\section{Experimental protocol}

Before the participants started the working day, they answered a questionnaire containing sociodemographic and behavioral variables. Drug use, smoking and alcohol intake variables were collected according to the instrument proposed by the World Health Organization ${ }^{9}$. Next, $10 \mathrm{~mL}$ of 
blood was drawn through venipuncture using a short catheter performed by a trained nurse, deposited in three tubes, two tubes with EDTA and one with clot activator for later analysis of $\mathrm{CK}$ and oxidative stress markers. The subjects were then randomized to perform the working day in one of the following conditions: using GCS (SIGVARIS ${ }^{\circledR}$ - Switzerland, mean compression between 18-21 mmHg) or placebo (conventional stockings of color and texture similar to GCS, KANXA ${ }^{\circledR}$ - Brazil, with no compression).

After the end of the working day, a second blood collection (eight hours after the first one) was performed to analyze the oxidative stress markers. After 16 hours from the end of the working day and before they start a new working day, the third blood sample was collected for analysis of the CK post working day. One week after the first randomized condition, the participants reversed the experimental condition: subjects who used placebo received GCS and vice versa. The participants and those responsible for the blood analysis were blinded (Figure 1).

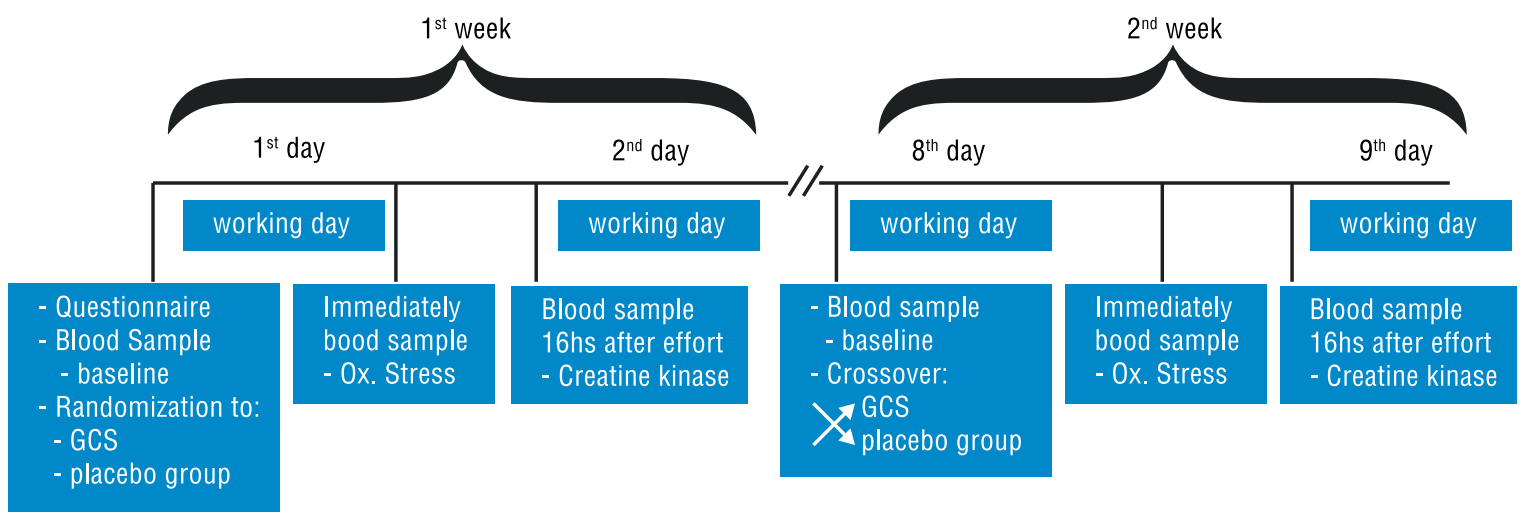

Figure 1- Intervention schedule. GCS- graded compression stockings.

\section{Creatine kinase and oxidative stress markers analysis}

The blood samples were centrifuged at $3000 \mathrm{rpm}$ for 10 minutes, the $1.5 \mathrm{~mL}$ aliquots of plasma was placed in tubes. The erythrocytes were isolated, washed with a physiological solution, diluted in water and stored in an ultra-freezer $\left(-80^{\circ} \mathrm{C}\right)$ for further analysis.

The CK activity was determined using a commercial kit (Roche ${ }^{\circledR}$ Cobas), according to the manufacturer's recommendations and expressed in U/L.

The TBARS (thiobarbituric acid) analysis was determined according to Esterbauer \& Cheeseman ${ }^{10}$. The analysis of total thiol content was performed by the method of Aksenov \& Markesbery ${ }^{11}$. The SOD (Superoxide Dismutase) activity was determined according to the method described by Misra and Fridovich ${ }^{12}$ using the commercial RANSOD ${ }^{\circledR}$ kit (Randox Laboratories, UK). The activity of CAT (Catalase) enzyme was verified by the method described by Aebi (1984) based on the decomposition of $\mathrm{H}_{2} \mathrm{O}_{2}$, measured by spectrophotometry at $240 \mathrm{~nm}$, at room temperature ${ }^{13}$. The activity of GPx (Glutathione Peroxidase) was determined by a commercial kit from Randox Laboratories Ltd (United Kingdom) according to the manufacturer's recommendations. Activity was expressed in units/mg of protein. 


\section{Statistical analysis}

The scores were entered in the Epi Data 3.1 software. After checking for errors, data were transferred to the statistical software STATA 12.0. Initially, the Shapiro-Wilk test was used to verify the distribution of the variables and the Bartlet test to verify the homogeneity of the variances. Additionally, two-way ANOVA (two conditions and two moments) was used for the analysis of the outcomes, and the "Contrast" command of the Stata software was used to evaluate the interaction. Data are expressed as mean \pm standard deviation and the level of significance was $p<0.05$.

\section{RESULTS}

Thirteen randomly chosen garbage collectors participated in the study. All subjects were adult males; most of them black skin color (76.9\%), ranging from 21 to 35 years old (mean $25.4 \pm 5.2$ years). Most of the subjects were married or lived with a partner (53.9\%) and did not complete elementary school (58.5\%). The collectors had an average family income higher than two minimum wages (US\$ $670.7 \pm 115.7$ dollars), and the majority had been working in the garbage collection company for more than 12 months (53.6\%). All participants showed eutrophic body mass index and the majority did not smoke (84\%), did not use medications (92.3\%) and drank alcoholic beverages regularly (53.9\%) (Table 1). During the study, there were three losses, which occurred due to work accident, family problems and difficulty in blood collection, respectively.

Figures 2 and 3 describe the results of the muscle damage and oxidative stress markers before and after intervention, intra and inter conditions of variables analyzed in the study, respectively. Regarding muscle damage marker (CK), no significant differences were found intra and between conditions. Additionally, the same lack of significance was observed in the oxidative stress markers catalase, TBARS and glutathione peroxidase enzymes. On the other hand, at the post-workday, the total thiol content showed a statistically significant difference between the conditions $(p=0.04)$, and SOD enzyme presented statistically significant changes $(\mathrm{p}=0.004)$, increasing SOD levels in the placebo condition only.

\section{DISCUSSION}

The present study aimed to determine the acute effects of the GCS use on muscle damage and oxidative stress markers of the garbage collectors. Regarding the muscle damage marker, unlike the results of a study by Duffield \& Portus (2007) which found a reduction in CK levels in cricket players 24 hours after a 30 -minute repeated sprint protocol, the present study did not find statistically significant differences between de conditions (GCS vs placebo $)^{14}$. However, our results corroborate with the findings from Ali et al. (2010) and Bieuzen et al. (2014) while studying runners not garbage 
Table 1. Prevalence of sociodemographic and work-related variables of garbage collectors. $(\mathrm{N}=13)$

\begin{tabular}{lc}
\hline Variables & $\begin{array}{c}\text { Prevalence N (\%) or } \\
\text { Mean (SD) }\end{array}$ \\
\hline Age (years) & $25.4(5.2)$ \\
\hline Income (US dollars) & $670.7 \pm 115.7$ \\
\hline Skin color & $3(25.1)$ \\
\hline White & $10(74.9)$ \\
\hline Black & \\
\hline Schooling (years) & $8(61.5)$ \\
\hline Incomplete primary school & $5(38.5)$ \\
\hline Complete primary school or more & \\
\hline Marital status & $7(53.9)$ \\
\hline Married or with a partner & $6(46.1)$ \\
\hline Single, with no partner or divorced & \\
\hline Smoking & $11(84.6)$ \\
\hline No & $2(15.4)$ \\
\hline Yes & $6(46.1)$ \\
\hline Drink alcohol & $7(53.9)$ \\
\hline No & \\
\hline Yes & $13(100.0)$ \\
\hline Body mass index (kg/m²) & $0(0.0)$ \\
\hline Eutrophic & $6(46.1)$ \\
\hline Overweight/Obesity & $7(53.9)$ \\
\hline Lork time (months) & $12(92.3)$ \\
\hline Ness than 12 & $1(7.7)$ \\
\hline Yes more & \\
\hline
\end{tabular}

Placebo $\square$ CGS
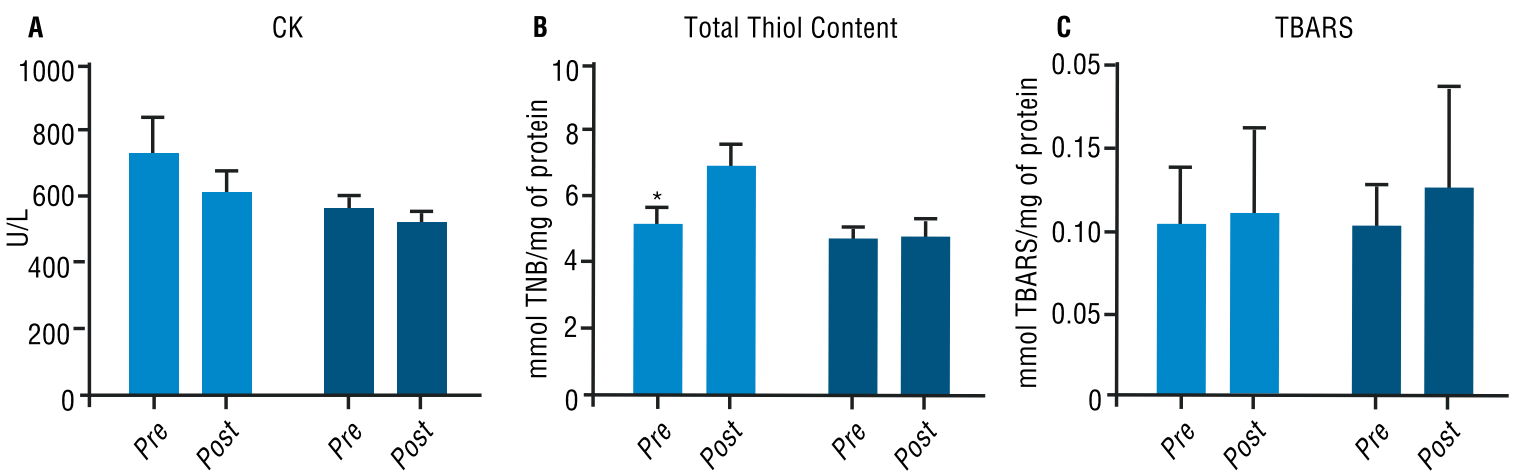

Figure 2 - Pre-and-post-workday activity of the creatine kinase (CK) enzyme and pro-oxidant markers using placebo or graded compression stockings (GCS). In A, CK activity in serum; in B, total thiol content (TTC); and in C, TBARS (Thiobarbituric acid reactive substances) levels are shown. * Significant difference between pre and post moments in the condition not using GCS $(p=0.04)$.

collectors $^{5,15}$. In the present study, the concentration of CK was measured 16 hours after the end of the activity, respecting the peak of this enzyme in the blood that is from 12 to 24 hours for long runs, an activity that is closer to that of garbage collectors during work ${ }^{16}$. It is possible that the 
Placebo DCG
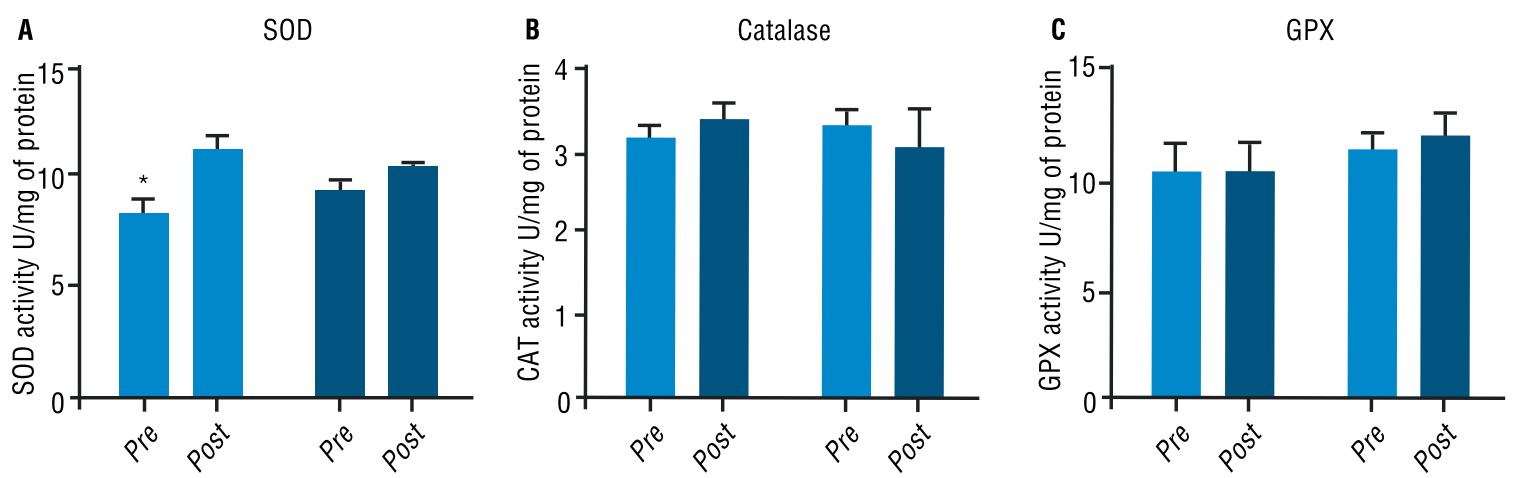

Figure 3 - Pre- and post-workday antioxidant enzymes using placebo or graduated compression stockings (GCS). In A, Activity of the enzyme superoxide dismutase (SOD) in blood samples from waste collectors. In B, activity of the enzyme catalase (CAT). In C, Activity of the enzyme Glutathione Peroxidase (GPx). ${ }^{*}$ Significant difference between pre and post activity in the control group $(p=0.004)$.

adaptation of the workers to the labor activity and their physical fitness have influenced the results so as not to change the concentration of $\mathrm{CK}$ in both conditions and moments.

In addition, CK may also be influenced by demographic characteristics, such as sex and ethnicity, that is, men and individuals of African descent have higher concentrations than women and white, Hispanic and Asian descendants ${ }^{17}$. As the garbage collectors were men (100.0\%) and mostly black (76.9\%), the high concentrations of CK presented by workers in both conditions and moments are probably justified.

Oxidative stress markers were included in the present study considering that garbage collection requires higher physical capacity. Consequently, the work requires higher oxygen consumption than other labor activities ${ }^{18}$ causing the production of reactive oxygen species (ROS), nitrogen (RNS) and free radicals simultaneously.

Thus, it was investigated whether GCS could reduce deleterious effects caused by oxidative stress ${ }^{19}$, using thiobarbituric acid reactive substances, total thiol content (glutathione and sulfhydryl concentrations) and CAT, GPx and SOD antioxidant enzymes ${ }^{20,21}$. Considering the results found in the present study, it is suggested that the use of GCS in a workday exerted acute protection against oxidative stress - antioxidant enzyme SOD $(\mathrm{p}=0.004)$ and total thiol content $(\mathrm{p}=0.04)$ - in the situation using placebo at the post-workday moment in relation to the initial measurements.

The SOD experienced a significant increase in the placebo situation. This antioxidant enzyme has a greater activity in muscles with high oxidative capacities (high percentage of slow contraction muscle fibers), mainly at mitochondrial site. This is the place where cellular respiration occurs, a process in which organic molecules are used in the manufacture of ATP, the main energy source of cells. Therefore, it is likely that the type of labor activity of garbage collectors has induced energy production in a significant way ${ }^{22}$. A similar result was found in a study conducted by Brites et al. ${ }^{23}$ where 30 soccer adult players were involved in a training program against a control group of 12 non-active subjects; blood collection was performed 12 hours after the end of one match and the authors showed a significant increase in SOD enzyme 
activity $^{23}$. In this sense, the lack of difference in the GCS situation may indicate that this clothing item acutely attenuated the oxidative stress levels, since the use of stockings kept the levels of these enzymes near rest levels.

The oxidative stress marker total thiol content showed a significant increase in the pre-to-post workday in the placebo situation. Thiols are multifunctional molecules, and one of their functions is to play an antioxidant role, having the capacity to act as reducing agents, binding to ROS and neutralizing the oxidative potential of these molecules ${ }^{24}$. The concentration of this marker provides an overview of the level of oxidative attack to proteins. In the present study, besides the good physical fitness showed by collectors, the increase in the marker may have occurred due to an acute response, explained by the high exertion of the physical task required for the collection of garbage. This energetic expenditure triggers the increase of oxidative stress and the antioxidant response of the organism ${ }^{19}$. A similar response was reported by Quindry et al..$^{25} ; 9$ men aged between $18-30$ years old completed a maximum exercise test and three additional submaximal tests with an interval of one week among them. Blood samples were collected 1 and 2 hours after the tests. The demands from physical exercise were associated with dramatic elevations of biomarkers of oxidative stress. In this sense, considering the lack of significant difference in GCS situation, it is probably that the acute use of compression stockings prevented a thiol marker increase during the workday.

The TBARS marker together with the antioxidant enzymes CAT and GPx did not show statistically significant acute changes in both situations. This may have been due to the fact that although the work activity had a high volume, garbage collectors may have such a high physical fitness that the intensity and/or time of exposure to physical activity may not have been sufficient to trigger the increase of other antioxidant enzymes (CAT and $\mathrm{GPx})^{26}$. These findings corroborate with the results found in similar studies. Powers et al. ${ }^{23}$, in their systematic review, concluded that aerobic endurance training did not alter CAT activity acutely ${ }^{27}$. In another study conducted by Djordjevic et al. ${ }^{28}$, no significant difference was found in the TBARS concentration shortly after a single adult handball match ${ }^{28}$. Groussard et al. ${ }^{29}$ when analyzing the effects of a maximal bicycle training on antioxidant enzymes, did not find differences in GPx after intervention ${ }^{29}$. Thus, these oxidative stress markers do not always respond to a single training session.

It is important to highlight that this study may present limitations. The garbage collectors had only one day off weekly, so it was impossible to assess the effects of the CK enzyme to respect its half-life, the peak of which seems to occur 48 hours after intense physical activity.

\section{CONCLUSIONS}

GCS use was efficient to improve acutely the antioxidant SOD and total thiol content activity in waste collectors. In this sense, we conclude that the acute use of GCS may contribute to minimize the deleterious effects of the high physical requirement from the garbage collection task. 


\section{COMPLIANCE WITH ETHICAL STANDARDS}

\section{Funding}

This research did not receive any specific grant from funding agencies in the public, commercial, or not-for-profit sectors.

\section{Ethical approval}

Ethical approval was obtained from the local Human Research Ethics Committee -60777916.2.0000.5313 and the protocol (no. 1.873.746) was written in accordance with the stan dards set by the Declaration of Helsinki.

\section{Conflict of interest statement}

The authors have no conflict of interests to declare.

\section{Author Contributions}

Conceived and designed the experiments: AMA, RKC, RBO, AJR. Performed the experiments: AMA, RKC. Analyzed the data: AMA, RKC, RBO, AJR. Contributed reagents/materials/analysis tools: AMA, FMS, PSO, MSS, RMS. Wrote the paper: AMA, RKC, RBO, FMS, MPF, PSO, MSS, RMS, AJR.

\section{REFERENCES}

1. Cardoso RK, Rombaldi AJ, Silva MC. Osteomuscular disorders and associated factors among solid waste collectors of two middle-sized cities from the South of Brazil. Rev Dor 2014; 15(1):13-16.

2. Cruzat VF, Rogero MM, Borges MC, Tirapegui J. Current aspects about oxidative stress, physical exercise and supplementation. Rev Bras Med Esporte 2007; 13(5):336-42.

3. Kraemer WJ, Bush JA, Wickham RB, Denegar CR, Gomes AL, Gosthalk LA, et al. Continuous compression as an effective therapeutic intervention in treating eccentric-exercise-induced muscle soreness. J Sport Rehabil 2001; 10: 11-23.

4. Miyamoto N, Hirata K, Mitsukawa N, Yanai T, Kawakami Y. Effect of pressure intensity of graduated elastic compression stocking on muscle fatigue following calf-raise exercise. J Electromyogr Kinesiol 2011; 21(2):249-54.

5. Bieuzen F, Brisswalter J, Easthope C, Vercruyssen F, Bernard T, Hausswirth C. Effect of wearing compression stockings on recovery after mild exercise-induced muscle damage. Int J Sports Physiol Perform 2014; 9: 256 -264, 2014.

6. Vasconcelos RC, Lima FPA, Camarotto JA, Abreu ACMS, Coutinho Filho AOS. Aspects of the complexity of domestic waste collection: management of street work variability. Gest Prod 2008; 15:407-19.

7. Machado CN, Gevaerd MS, Goldfeder RT, Carvalho T. Exercise effects on serum levels of creatine kinase in ultradistance triathletes in the course of a competition period. Rev Bras Med Esporte 2010; 16(5):378-81.

8. Aguiló A, Tauler P, Fuentespina E, Tur JA, Córdova A, Pons A. Antioxidant response to oxidative stress induced by exhaustive exercise. Physiol Behav 2005; 84 (1):1-7.

9. Fleck MPA. The World Health Organization instrument to evaluate quality of life (WHOQOL-100): characteristics and perspectives. Cienc Saúde Coletiva 2000; 5(1):33-8. 
10. Esterbauer H, Cheeseman KH. Determination of aldehydic lipid peroxidation products: malonaldehyde and 4-hydroxynonenal. Methods Enzymol 1990; 186:407-21.

11. Aksenov MY, Markesbery WR. Changes in thiol content and expression of glutathione redox system genes in the hippocampus and cerebellum in Alzheimer's disease. Neurosci Lett 2001; 302(2/3):141-45.

12. Misra HP, Fridovich I. The role of superoxide anion in the autoxidation of epinephrine and a simple assay for superoxide dismutase. J Biol Chem 1972; 247(10):3170-5.

13. Aebi H. Catalase in vitro. Methods Enzymol 1984; 105:121-6.

14. Duffield R, Portus M. Comparison of three types of full-body compression garments on throwing and repeat-sprint performance in cricket players. Rev Bras Med Esporte 2007; 41:409-14.

15. Ali A, Creasy RH, Edge JA. Physiological effects of wearing graduated compression stockings during running. Eur J Appl Physiol 2010; 109:1017-25.

16. Clarkson PM, Hubal MJ. Exercise-induced muscle damage in humans. American Am J Phys Med Rehabil 2002; 8(11):52-69.

17. Neal RC, Ferdinand KC, Ycas J, Miller E. Ethnicity, Gender, Age, and creatine kinase levels. Am J Med 2009; 122(1):73-8.

18. BanfI G, Colombini A, Lombardi G, Lubkowska A. Metabolic markers in sports medicine. Adv Clin Chem 2012; 56:1-54.

19. Finaud J, Scislowski V, Lac G, Durand D, Vidalin H, Robert A. Antioxidant status and oxidative stress in professional rugby players: evolution throughout a season. Int J Sports Med 2006; 7(2):87-93.

20. Powers SK, Talbert EE, Adhihetty PJ. Reactive oxygen and nitrogen species as intracellular signals in skeletal muscle. J Physiol 2011; 589(9):2129-38.

21. Vincent HK, Powers SK, Demirel HA, Coombes JS, Naito H. Exercise training protects against contraction induced lipid peroxidation in the diaphragm. Eur J Appl Physiol Occup Physiol 1999; 79(3): 268-273.

22. Powers SK, Lennon SL. Analysis of cellular responses to free radicals: focus on exercise and skeletal muscle. P Nutr Soc. 1999; 58: 1025-1033.

23. Brites FD, Evelson PA, Christiansen MG, Nicol MF, Basílico MJ, Wikinski RW, Llesuy SF. Soccer players under regular training show oxidative stress but an improved plasma antioxidant status. Clin Sci 1999; 96(4):381-85.

24. Sen CK, Packer L. Thiol homeostasis and supplements in physical exercise. Am J Clin Nutr 2000; 72 (suppl): 653-69.

25. Quindry JC, Stone WL, King J, Broeder CE. The effects of acute exercise on neutrophils and plasma oxidative stress. Med Sci Sports Exerc 2006; 35:1139-45.

26. Schneider CD, Silveira MM, Moreira JCF, Belló-Klein A, Olliveira AR. Effect of the ultra-endurance exercise on oxidative stress parameters. Rev Bras Med Esporte 2009; 1; 5:89-92.

27. Powers SK, Ji LL, Leeuwenburgh C. Exercise training-induced alterations in skeletal muscle antioxidant capacity: a brief review. Med Sci Sports Exerc 1999; 3:987-97.

28. Djordjevic DZ, Cubrilo DG, Puzovic ZS, Vuletic MS, Zivkovic NS, Barudzik NS, et al. Changes in athlete's redox state induced by habitual and unaccustomed exercise. Oxid Med Cell Longev 2012;2012:805850

29. Groussard C, Rannou-Bekono F, Machefer G, Chevanne M, Vicent S, Sergent $\mathrm{O}$, et al. Changes in blood lipid peroxidation markers and antioxidants after sprint anaerobic exercise. Eur J Appl Physiol. 2013; 89:14-20.

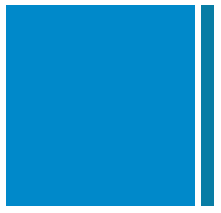

Corresponding author

Rodrigo Kohn Cardoso

Federal University of Pelotas

Post-graduation Program in Physical Education; 625, Luis de Camões St.,

Três Vendas. Zip code 96055-630, Pelotas/RS, Brazil

E-mail: rodrigokohn21@yahoo.com.br 